\title{
Aconcagua peak geodynamics from GPS observations, Mendoza, Argentina: preliminary results
}

\author{
M. L. Mateo, L. E. Lenzano, and S. M. Moreiras \\ Instituto Argentino de Nivología, Glaciología y Ciencias Ambientales - CCT, Av. Ruiz Leal s/n, Parque Gral, San Martin \\ (CP 5500), Mendoza, Argentina
}

Received: 30 April - Revised: 12 August - Accepted: 14 August - Published: 14 December 2009

\begin{abstract}
In 2005, the SIGMA Program (Mount Aconcagua GNSS Research System) was implemented to investigate the geodynamics of the Aconcagua mountain region in the Central Andes. For this purpose, a continuously recording GPS station, ACON, was installed on the summit of Mount Aconcagua at $6.292 \mathrm{~m}$ a.s.l. The installation required special technology to support the equipment under extreme climatic conditions. The power supply system was optimized in 2008, so that a greater quantity of data could be recorded. This, in turn, will lead to more accurate estimates of displacement of the Aconcagua peak. Preliminary results from the ACON station indicate an average horizontal velocity of $0.023 \pm 0.0001 \mathrm{~m} / \mathrm{yr}$ toward NE in 2 time windows between 2006 and 2008.
\end{abstract}

\section{Introduction}

At $32^{\circ} \mathrm{SL}$, the Central Andes comprise three morphostructural units with $\mathrm{N}-\mathrm{S}$ trends, west to east: Cordillera Principal (CP), Cordillera Frontal (CF), and Precordillera (P) (Fig. 1). The Western CP, where Aconcagua peak is situated, is characterised by Jurassic, Cretaceous, and Oligocene-Miocene continental volcaniclastic rocks intruded by Miocene-Pliocene dikes. Structurally, it corresponds to the Aconcagua fold and thrust tectonic belt (AFTB) integrated by westward-verging reverse slip that experienced combinations of compressional, extensional, and shear tectonics throughout the Late Cenozoic (Giambiagi et al., 2003; Charrier et al., 2007).

The Andean orogen is a result of the compressive regime of the Nazca Plate subducting beneath the South American

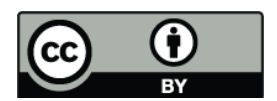

Correspondence to: M. L. Mateo (lmateo@mendoza-conicet.gov.ar)
Plate. An increase in plate convergence rate was the responsible for the neotectonic evolution of this range $25 \mathrm{Ma}$ ago resulting in the progressive building of the three morphostructural units (Ramos, 1996). This compressive regime continues uplifting the Andes range. A displacement of $3 \mathrm{~cm}$ per year has been measured on the Argentinean Precordillera (Kendrick et al., 2006), whereas subduction rate at the study area latitude had been estimated around $2 \mathrm{~cm}$ per year (Cross and Pilger, 1982). As Aconcagua peak (6962 m a.s.l.) is the main topographic expression of the Central Andes, a GNSS Continuous Station was installed on it in March 2006 as part of the SIGMA Program (Mount Aconcagua GNSS Research System) that was focused on determining displacement and the vertical component of velocity of this summit (Lenzano, 2006). However, this program now constitutes multidisciplinary researches (geodesy, geophysics, glaciology, geology, and geomorphology). For example, glaciers' volumetric variations have been established by analysing satellite images and mass waste processes have been identified in the Aconcagua Park (Moreiras et al., 2008). This research provides basic studies for the management plan of this natural reserve (Blanco et al., 2007).

\section{ACON installation: operation and data transmission}

Given the extreme climatic conditions of the study area, installation of the ACON station was a laborious process. The equipment (cables, batteries, solar panels, etc.) must operate at temperatures below $-35^{\circ} \mathrm{C}$, winds faster than $200 \mathrm{~km} / \mathrm{h}$ and heavy snow precipitation; hence a very advanced technology must be implemented. For this purpose, the SIGMA program called upon highly qualified human resources for developing the infrastructure needed to supply power to the equipment and to keep a data communications link functioning.

Published by Copernicus Publications on behalf of the European Geosciences Union. 


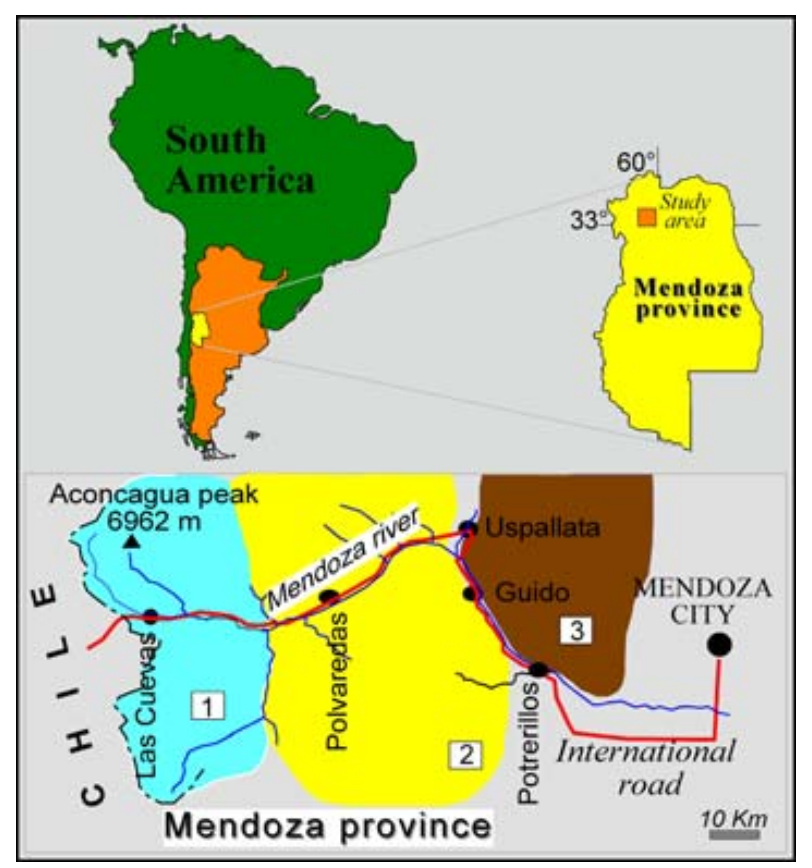

Fig. 1. Mendoza Province 1(CP) 2(CF) 3(P).

Although the station was installed in March 2006, (Lenzano et al., 2007) the power supply had some failures, resulting in data loss. During the 2008 field season, the power supply system was optimized, without disregarding easy transportation and simple assemblage. We installed an energy controller connected to two parallel solar panels. The controller consistently provides $12 \mathrm{~V}$ to the GPS receiver. Another panel connected to a second controller also provides energy to the receiver through its secondary power input. The station transmits data via line-of-sight radio link from the summit to the Horcones park rangers' central office (Fig. 2). Data is recorded daily on a PC, either manually or automatically.

A third controller provides power to the data transmission radio that is connected to an additional solar panel (third panel). Finally, a fourth controller prevents overcharging (i.e., greater than 14.1 volts) to protect batteries and equipment from excessive voltage. When batteries reach a charge less than 11.5 volts, the controller disconnects the power supply to the equipment. When the batteries recharge to 12.6 volts, the controller reconnects them to the equipment.

\section{Data processing methodology}

There is a network of permanent GPS stations that belong to the SIRGAS (Sistema de Referencia Geocéntrico para las Américas) (Fortes et al., 2005) in America. These stations are installed and maintained by institutions working in SIRGAS member countries. The data acquired by these sta-

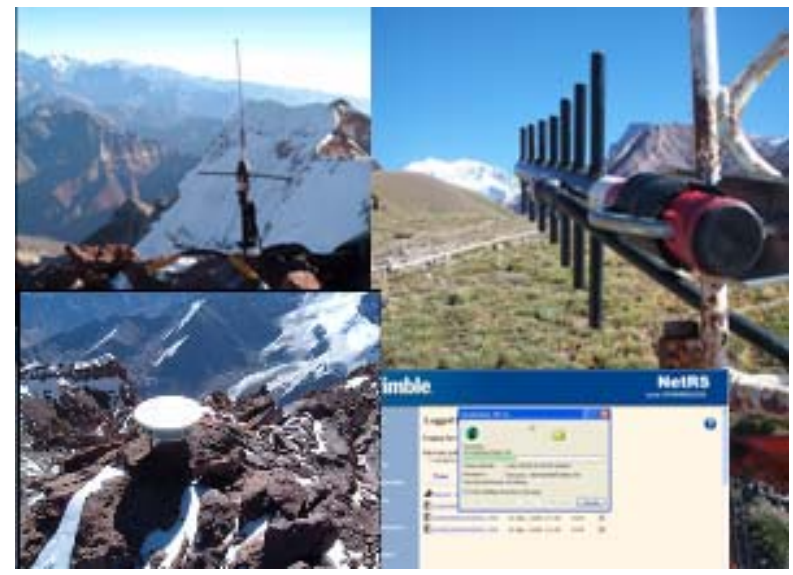

Fig. 2. Station ACON. Data Transmission from the Summit.

tions are freely available on the Internet (http://sopac.ucsd. edu/) (http://www.gnssargentina.org.ar/). Among the products available after processing the satellite data are coordinates of each station and its velocity with respect to a specified reference frame. It should be taken into account that the period between the first observation and the last one must be sufficiently long to achieve a reliable and representative velocity (Seemüller et al., 2008).

In this study, we estimated the velocity of the ACON station within a network of stations on the South American Plate, using the Bernese 5.0 software for the processing. We included GNSS stations located on different zones of the plate some in stable zone (for example in the eastern Argentina and Brazil) and others in the zone of rapid displacement (in western Chile) (Fig. 4). The following stations were utilised: BRAZ (Brasilia - Brazil), BRTF (Fortaleza, Brazil), CONZ (Concepcion - Chile), LPGS (La Plata - Argentina), MZAC (Mendoza - Argentina), SANT (Santiago - Chile), SMAR (Santa María - Brazil) and UNSA (Salta Argentina).

The data processing was divided in two stages. The first stage was pre-processing, in which ACON data were analysed individually considering the continuity of daily records and selecting only those exceeding $12 \mathrm{~h}$ of daily recording (Fig. 3a). We obtained precise satellite orbits and terrestrial orientation parameters calculated by the IGS (International GNSS Service Terms of Reference), which allowed us to obtain very accurate results. Station coordinates and velocities used for the adjustment were from the SIRGAS solution for the 2008 year (Seemüller et al., 2008).

The second stage of data processing made use of Bernese 5.0 software. For this we required: (1) a priori coordinates calculated from SIRGAS velocities, (2) synchronized clocks among satellite-receiver, and (3) manually generated simple differences for the desired baseline vectors. Finally, vectors were obtained by double phase differences that were 


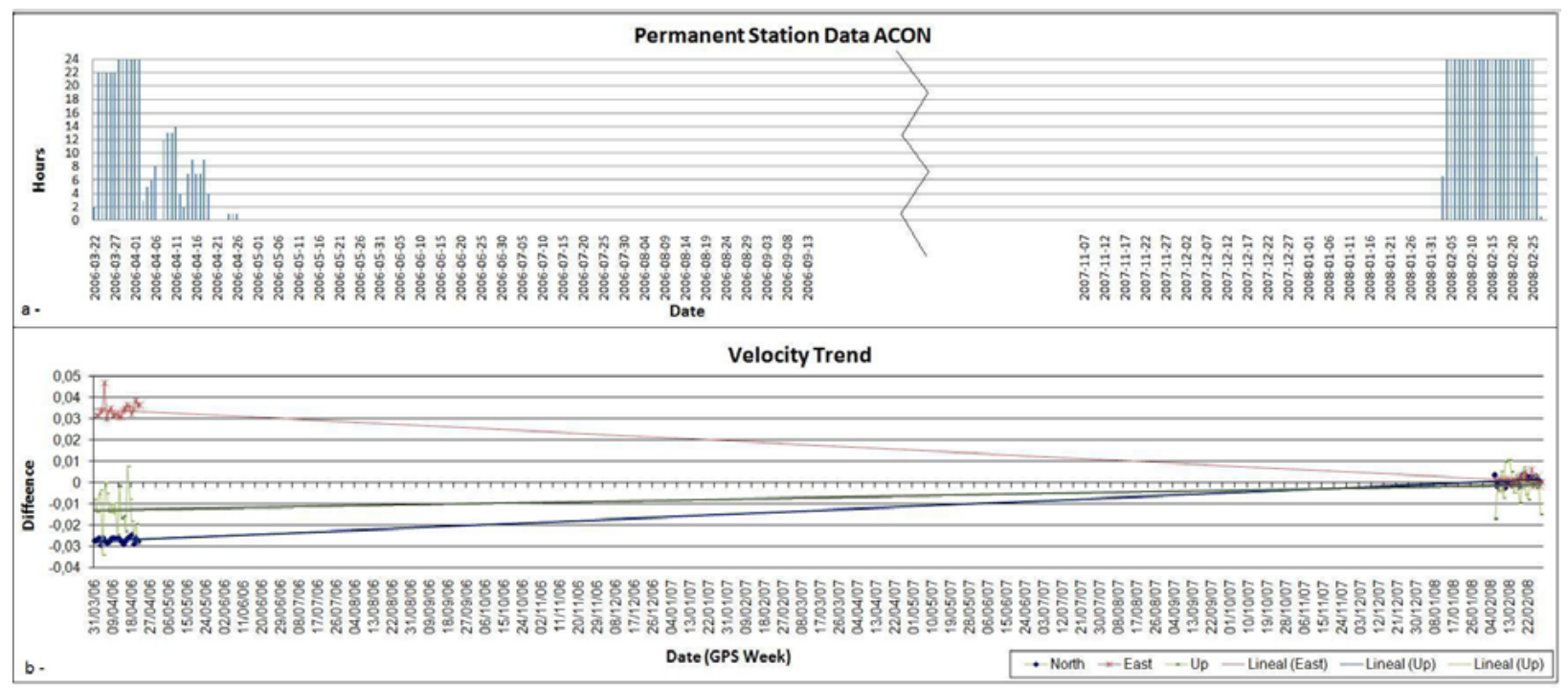

Fig. 3. (a) Time serie data from the Acon GPS permanent station, (b) Displacement vectors.

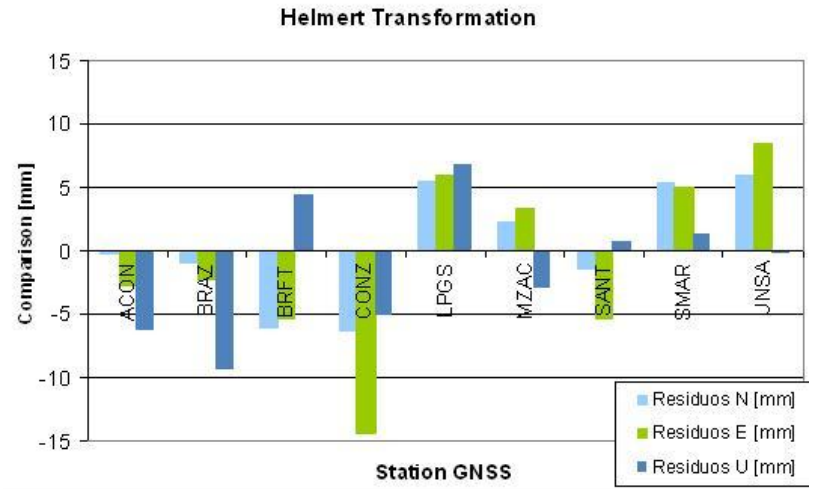

Fig. 4. Helmert Transformation.

adjusted as a net by the strategy of NNR and NNT adjustment (see below, Hugentobler et al., 2006), resulting final station coordinates and velocities.

\section{Results}

Our analysis allowed us to make preliminary estimates of the coordinates and velocity of the ACON GPS station (Fig. 3b).

\subsection{Adjustment of the net}

The network was adjusted with Bernese GPS software 5.0, based on the daily processed normal equation files. The network was transformed into the IGS05 reference frame by constraining the positions and velocities of four long-lived, stable IGS stations (SANT, LPGS, BRAZ, UNSA) under nonet-rotation and no-net-translation conditions. Selected link-

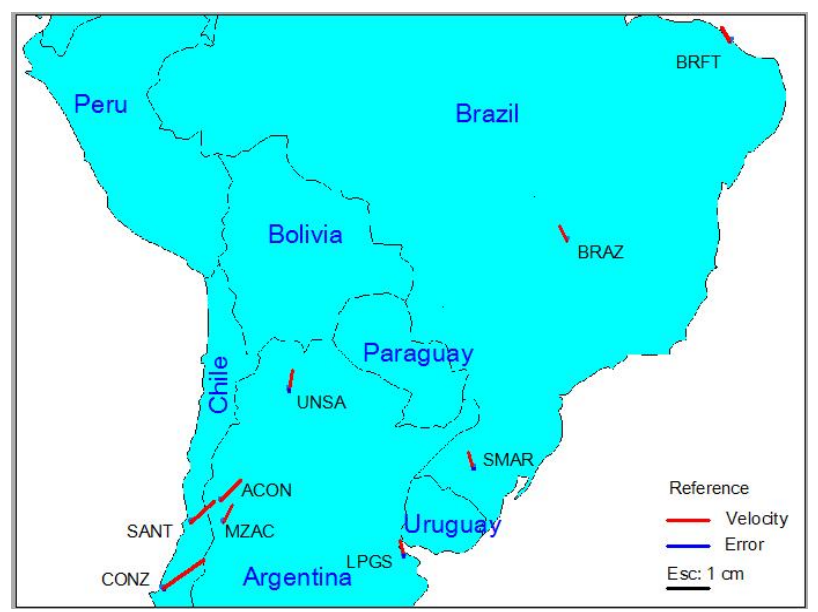

Fig. 5. Velocity trends of SIRGAS station net and ACON station $(0.023 \pm 0.0001 \mathrm{~m} / \mathrm{yr})$.

ing stations have long observation histories supporting accurate estimates for the coordinates and velocities of stations in the local net (Seemüller et al., 2008).

After the link of the network with the IGS05 reference frame, our results were compared with a free net by a Helmer transformation (Fig. 4). As differences are on average less than $10 \mathrm{~mm}$, we can be assured that the reference frame transformation did not appreciably deform our net.

\subsection{Displacement}

A vertical displacement of $0.0065 \pm 0.0001 \mathrm{~m} / \mathrm{yr}$ could be calculated for the Aconcagua peak evidencing its progressing uplifting. Thus, we estimated a northern horizontal 
velocity $0.0162 \pm 0.0001 \mathrm{~m} / \mathrm{yr}$ and eastern horizontal velocity $0.0160 \pm 0.0001 \mathrm{~m} / \mathrm{yr}$ what results in an average horizontal velocity of $0.023 \pm 0.0001 \mathrm{~m} / \mathrm{yr}$ for the ACON GPS station (Fig. 5). Our estimated velocities of SIRGAS stations used as control in our network (CONZ, MZAC, SMAR and BRFT), are in good agreement with those calculated by SIRGAS (Seemüller et al., 2008), adding credence to the velocity we estimated for ACON GPS station.

\section{Conclusion and discussion}

Our preliminary results indicate a mean velocity of $0.023 \pm 0.0001 \mathrm{~m} / \mathrm{yr}$ with NE trends at the ACON GPS station. This range matches with previously established displacements in the region, whereas the north-eastward azimuth of horizontal velocity at ACON likewise is consistent with the earlier general results of SIRGAS study. Herein these findings validate the regional SIRGAS framework; however we hope to obtain more continuous and accurate data in the next four years regarding plate motion in this area. To achieve this purpose an extra continuous station will be installed in the near future outside of the Aconcagua massif. In addition, we are starting to develop gravimetric studies for determining gravimetric anomalies in the study area.

Acknowledgements. We want to express our thanks to Rene Garreaud who invited us to participate in this special edition of ADGEO. Gratefully as well to Timothy Dixon and both anonymous reviewers.

Edited by: B. Tilling

Reviewed by: T. Dixon and 2 other anonymous referees

\section{References}

Blanco, M., Euillades, L., Cabrera, G., Lenzano, L., and Barón, J.: Infraestructura y Monumentación de la Estación GPS en el Cerro Aconcagua, Geoacta, 32, , 213-215, 2007.

Charrier, R., Pinto, L., and Rodríguez, M. P.: Tectonostratigraphic evolution of the Andean orogen in Chile, in: The Geology of Chile, edited by: Moreno, T. and Gibbons, W., Geological Society, London, 21-114, 2007.
Cross, T. A. and Pilger, R. H.: Controls of subduction geomotry, location of magmatic arc, and tectonics of arc and back-arc regions, Geol. Soc. Am. Bull., 93, 545-562, 1982.

Fortes, P., Lauría, E., Brunini, C., Amaya, W., Sánchez, L., and Drewes, H.: SIRGAS - a geodetic enterprise, Coordinates, online available at: http://www.mycoordinates.org/sirgas-may-06. php, 2005.

Giambiagi, L. B., Ramos, V., Godoy, E., Álvarez, P., and Orts, S.: Cenozoic deformation and tectonic style of the Andes between $33^{\circ}$ and $34^{\circ}$ south latitude, Tectonics, 22, 1041, 15-19, 2003.

Hugentobler, U. D. R., Friedez, P., and Meindl, M. (Eds.): Bernese GPS Software Version 5.0. Astronomical Institute, University of Berne, Berne, 2006.

Kendrick, E., Brooks, B. A., Bevis, M., Smalley Jr., M., Lauria, L., Araujo, M., and Parra, H.: Active orogeny of the South-Central Andes studied with GPS geodesy, Revista Asociación Geológica Argentina, 61(4), 555-566, 2006.

Lenzano L.: Programa SIGMA, Proccedings of Jornadas de Investigación, September 2006, Universidad Nacional De Cuyo, 2006.

Lenzano, L., Mackern, V., Lenzano, M. G., and Robín, A. M.: Estación Permanente GPS "ACON", Instalación y funcionamiento, Monte Aconcagua, Mendoza, Argentina, Geoacta 32, 35-39, 2007.

Lenzano, M. G., Leiva, J. C., and Lenzano, L. E.: Implementación de los Métodos de Fotogrametría Terrestre Digital y Procesamiento de Imágenes Satelitales, para el Monitoreo de los Glaciares Horcones Superior e Inferior, Resúmenes XXIII Reunión Científica de la Asociación Argentina de Geofísicos y Geodestas, Geoacta, Proccedings of XXIII Reunion Cientfica de la Asociación Argentina de Geofísicos y Geodestas, Bahía Blanca, Argentina, 121, 2006.

Moreiras, S. M., Lenzano, M. G., and Riveros, N.: Inventario de procesos de remoción en masa en el Parque provincial Aconcagua, provincia de Mendoza - Argentina. Multiequina, Latin American Journal of Natural Resources, 17, 129-146, 2008.

Ramos, V. A.: Evolución tectónica de la alta cordillera de San Juan y Mendoza. In: Victor Ramos (ed). Geología de la región del Aconcagua, provincias de San Juan y Mendoza. Subsecretaria de Minería de la Nación, Dirección Nacional del Servicio Geológico Anales, 24(1), 447-460, 1996.

Seemüller, W., Krügel, M., and Sánchez, L.: The position and velocity solution DGF08P01 of the IGS Regional Network Associate Analysis Centre for SIRGAS (IGS-RNAAC-SIR), DGFI Report No. 29, Munich, Germany, 110 pp., 2008. 